\title{
Newborn-Care Training in Developing Countries
}

\section{Citation}

Olson, Kristian R., Aya Caldwell, and Brett D. Nelson. "Newborn-care training in developing countries." N Engl J Med 362, no. 25 (2010): 2427-2428. doi:10.1056/NEJMc1004083

\section{Published Version}

doi:10.1056/NEJMc1004083

\section{Permanent link}

http://nrs.harvard.edu/urn-3:HUL.InstRepos:34450708

\section{Terms of Use}

This article was downloaded from Harvard University's DASH repository, and is made available under the terms and conditions applicable to Other Posted Material, as set forth at http:// nrs.harvard.edu/urn-3:HUL.InstRepos:dash.current.terms-of-use\#LAA

\section{Share Your Story}

The Harvard community has made this article openly available.

Please share how this access benefits you. Submit a story.

\section{Accessibility}


potential bias in the comparison of cure rates. Could the authors reanalyze the data with the exclusion of patients who had received previous malathion therapy and look only at the population that had received previous pyrethroid treatment? This analysis could provide a more unbiased comparison of ivermectin and malathion.

The authors also mention the potential risk of leukemia in children receiving pesticide treatment. In the study that they cite, ${ }^{2}$ the odds ratio for leukemia in children who had been treated with malathion, as compared with control subjects, was 0.7 ( $95 \%$ confidence interval [CI], 0.2 to 2.4 ). Since malathion is the only topical pesticide included in the study by Chosidow et al., the authors should note that there is no evidence linking malathion with childhood leukemia.

Howard Rutman, M.D.

Taro Pharmaceuticals

Hawthorne, NY

howard.rutman@taro.com

Dr. Rutman reports being the medical director of Taro Pharmaceuticals, which distributes malathion lotion in the United States. No other potential conflict of interest relevant to this letter was reported.

1. Chosidow O, Giraudeau B, Cottrell J, et al. Oral ivermectin versus malathion lotion for difficult-to-treat head lice. $\mathrm{N}$ Engl J Med 2010;362:896-905. [Erratum, N Engl J Med 2010;362:1647.] 2. Menegaux F, Baruchel A, Lescoeur B, et al. Household exposure to pesticides and risk of childhood acute leukaemia. Occup Environ Med 2006;63:131-4.

THE AUTHORS REPLY: Because malathion was our control, Rutman suggests that including subjects with head-lice persistence despite previous malathion treatment might introduce bias. However, failure to control head lice does not always mean treatment resistance. It might reflect insufficient application of the insecticide, reinfestation, or poor compliance. ${ }^{1}$ Our trial treatments were supervised, which perhaps explained malathion's "good" per- formance: $85 \%$ lice-free patients on day $15 . \mathrm{Nev}-$ ertheless, head-lice persistence 24 hours after application strongly suggests insecticide resistance. ${ }^{2}$ Reanalysis of the subgroup of patients who had undergone previous non-malathion therapy supports the robustness of our primary findings, with similar success rates: $95.9 \%$ (in 208 of 217 patients) for ivermectin versus $86.3 \%$ (in 201 of 233 patients) for malathion (absolute difference, 9.6 percentage points; 95\% CI, 2.2 to $16.9 ; \mathrm{P}=0.007$ ). At the cluster level, 110 of 117 patients $(94.0 \%)$ in the ivermectin group and 102 of 120 patients $(85.0 \%)$ in the malathion group were free of head lice (difference, 9.0 percentage points; 95\% CI, 1.1 to $17.1 ; \mathrm{P}=0.02)$. Menegaux et $a .^{3}$ found that treatment of pediculosis with insecticidal shampoo was associated with an increased risk of childhood acute leukemia (odds ratio, 1.9; 95\% CI, 1.1 to 3.2), with a dose-effect relationship. However, this study lacked statistical power with respect to the use of malathion since the findings were based on only 5 case subjects and 10 control subjects.

Olivier Chosidow, M.D., Ph.D.

Université Pierre et Marie Curie Paris 6

Paris, France

olivier.chosidow@hmn.aphp.fr

Bruno Giraudeau, Ph.D.

Université François-Rabelais

Tours, France

Jeremy Cottrell, M.S.

McNeil

High Wycombe, United Kingdom

Since publication of their article, the authors report no further potential conflict of interest.

1. Chosidow O. Scabies and pediculosis. Lancet 2000;355:819-26.

2. Chosidow O, Chastang C, Brue C, et al. Controlled study of malathion and d-phenothrin lotions for Pediculus humanus var capitis-infested schoolchildren. Lancet 1994;344:1724-7.

3. Menegaux F, Baruchel A, Bertrand Y, et al. Household exposure to pesticides and risk of childhood acute leukaemia. Occup Environ Med 2006;63:131-4.

\section{Newborn-Care Training in Developing Countries}

TO THE EDITOR: Carlo et al. (Feb. 18 issue $)^{1}$ report the results of the First Breath study of newborncare training in developing countries. Neonatal death is the leading cause of death among children, yet it receives little attention in research and programming. ${ }^{2,3}$ However, one of the study's findings, in particular, was somewhat unanticipated.

Although training in the Essential Newborn Care course was associated with a 30\% reduction in stillbirths, the study showed no significant benefit from training in the Newborn Resuscitation Program. We wish to underscore that these findings do not necessarily negate the potentially critical role that neonatal resuscitation training may play in these settings.

The study was, by design, limited in its capacity to assess the effect of neonatal resuscitation alone. First, all the birth attendants - both those 
in the intervention group and those in the control group - received resuscitation training and ventilation devices; only birth attendants for birth clusters that were randomly assigned to the Neonatal Resuscitation Program were given subsequent training in that program. Second, the study included a large number of physicians, who showed less benefit from training in the Essential Newborn Care course and who typically participate in a minority of births in these settings.

Neonatal resuscitation training could still play an important role among previously untrained, community-based, nonphysician providers those who deliver the majority of newborns in developing countries. ${ }^{4}$

Kristian R. Olson, M.D., M.P.H.
Massachusetts General Hospital
Boston, MA
krolson@partners.org
Aya Caldwell
CIMIT Global Health Initiative
Boston, MA
Brett D. Nelson, M.D., M.P.H.
MassGeneral Hospital for Children
Boston, MA
No potential conflict of interest relevant to this letter was re-
ported.

1. Carlo WA, Goudar SS, Jehan I, et al. Newborn-care training and perinatal mortality in developing countries. $\mathrm{N}$ Engl J Med 2010;362:614-23.

2. Lawn JE, Cousens S, Zupan J. 4 Million neonatal deaths: when? where? why? Lancet 2005;365:891-900.

3. Baqui AH, El-Arifeen S, Darmstadt GL, et al. Effect of community-based newborn-care intervention package implemented through two service-delivery strategies in Sylhet district, Bangladesh: a cluster-randomised controlled trial. Lancet 2008;371: 1936-44.

4. Wall SN, Lee AC, Niermeyer S, et al. Neonatal resuscitation in low-resource settings: what, who, and how to overcome challenges to scale up? Int J Gynaecol Obstet 2009;107:Suppl 1:S47-S62.

THE AUTHORS REPLY: Olson and colleagues are correct that further resuscitation training may not have had an additional effect, since resuscitation training had been taught as part of the Essential Newborn Care course. However, that initial resuscitation training was limited to basic knowledge and skills; our findings suggest that in-depth training may not be more effective. The overwhelming majority of the births $(87 \%)$ were not attended by physicians, so the lack of a benefit of more advanced resuscitation training was not due to having had a large proportion of deliveries attended by advanced practitioners.

Our cluster-randomized, controlled trial cannot answer the question of whether resuscitation training alone could reduce stillbirths or neonatal mortality. Some experts would consider it unethical to do such a randomized, controlled trial without providing the birth attendants in control clusters with some basic training. Therefore, we designed the trial to provide essential newborn-care training to all birth attendants as early as possible during the study. Furthermore, an integrated approach that includes training in resuscitation as part of a package of interventions may be the most effective and cost-effective approach. ${ }^{1}$

Waldemar A. Carlo, M.D.

University of Alabama at Birmingham

Birmingham, AL

wcarlo@peds.uab.edu

Linda L. Wright, M.D.

National Institute of Child Health and Human Development Bethesda, MD

Tyler D. Hartwell, Ph.D.

Research Triangle Institute

Research Triangle Park, NC

Since publication of their article, the authors report no further potential conflict of interest.

1. Darmstadt GL, Walker N, Lawn JE, Bhutta ZA, Haws RA, Cousens S. Saving newborn lives in Asia and Africa: cost and impact of phased scale-up of interventions within the continuum of care. Health Policy Plan 2008;23:101-17.

\section{The ABIM and Recertification}

TO THE EDITOR: In their Clinical Decisions article, Levinson et al. (March 11 issue) ${ }^{1}$ examine the value of the maintenance of certification (MOC) program of the American Board of Medical Specialties, as implemented by the American Board of Internal Medicine (ABIM). The article, which includes two essays offering the pros and cons of the MOC program as it is currently configured, presents the case of a hypothetical advanced-career physician who has "grandfather" status. Both the essay by Goldman et al. and the accompanying editorial by Drazen and Weinstein ${ }^{2}$ offer critiques 